\title{
Internet resources for sociology
}

\author{
By Gary A. McMillan, Margaret R. Dittemore, and Carol Ritzen Kem
}

\section{ACRL's Antbropology \& Sociology Section explores network resources}

$\mathbf{S}$ ociology - the scientific study of human social behavior-presents a daunting challenge to the Internet explorer. The discipline's theoretical, methodological, and substantive diversity renders almost every site and resource useful for sociological inquiry. In reviewing resources, we sought to develop a guide to help librarians introduce sociology faculty and students to the Internet. Thus, with library instruction in mind, it is wise to consider what sociology is not, e.g., neither socialism, social activism, social engineering, nor social work. Many of the entries cited will indeed lead one to applied social sciences resources, but we have attempted to focus on sites relevant to sociology as a discipline. We cite resources which are clearly "sociology-iclentified" in terms of sponsorship, production, participation, and/or use. A few key general sources that sociologists should find interesting (e.g., federal and funding-related information) are also included.

\section{Gateway systems: Aids to exploring the Internet for sociology resources}

- Berkeley Sociology Gopher. Identifies journals, data archives, Internet directories and guidebooks, and selected special collections and Web sites. Access: gopher://infolib.lib.berkeley. edu/11/resdbs/soci.

- NTIS FedWorld. This unparalleled omnibus gateway to federal-related sites includes pointers to the White House and Congress, the Bureau of the Census, the National Science Foundation, the National Institutes, other federal departments and independent agencies, and information clearinghouses such as the National Criminal Justice Reference Service. Access is provided to 130 -plus government bulletin boards not otherwise accessible. Access: http://www.fedworld.gov.

- Sociology Departments. Connect to more than 35 (and growing) sociology departments for descriptive program information plus hot-links to newly identified sociology sources. Access: http://www.shu.edu/ brownsam/v1/ institut.html or http://www.princeton.edu/ sociology/us_links.html.

- WwW Sociology Virtual Library. All types of resources are here, including scholarly and professional organizations, academic departments, research centers, and public and private institutions worldwide. Access: http:// www.w3.org/hypertext/DataSources/bySubject /Sociology/Overview.html.

- Yahoo's Sociology. The Yahoo ("Yet Another Hierarchical Officious Oracle") group represents another ongoing effort to identify and systematize Internet resources. $A C$ cess: http: //www.yahoo.com/social_science/ sociology.

\section{Scholarly discussion lists and electronic conferences}

Over thirty discussion groups were assessed through subscription or communication with the list owner. The following lists should have the broadest appeal to sociologists.

Gary A. McMillan is bead of the Social Work Library and sociology/antbropology bibliographer at Howard University, e-mail: mcmillan@cldc.boward.edu. Margaret $R$. Dittemore is the librarian of the Jobn Wesley Powell Library of Antbropology at the Smithsonian Institution Libraries, e-mail: libem054@sium.si.edu. Carol Ritzen Kem is the sociology collection bibliograpber at the George A. Smathers Libraries, University of Florida at Gainesville, e-mail: carokem@nerum.nerdc.ufl.edu. 
- ABSIST-L. For scholarly communication among members of the Association of Black Sociologists and associates. Access: LISTSERV@ CMUVM.CSV.CMICH.EDU.

- ANSS-L. For librarians and information specialists in anthropology and sociology, the list also serves as a communications medium for members of the ACRL Anthropology and Sociology Section (ANSS). Access: LISTSERV@ UCI.EDU.

- DEMOGRAPHIC-LIST. Demography and population studies list. Access: MAJORDOMO@ COOMBS.ANU.EDU.AU.

- EUROPEAN-SOCIOLOGIST. The European Sociological Association's list focuses on the sociological analysis of Europe. Access: MAILBASE@MAILBASE.AC.UK, message: join european-sociologist firstname lastname

- EVALTEN. A multidisciplinary discussion list for evaluation and statistical methods. $A C$ cess: MAJORDOMO@WORLD.STD.COM.

- FAMILY-SCI. The Family Science Network includes family sociology within the broader scope of behavioral and social science aspects of marriage and the family. Access: LISTSERV@UKCC.UKY.EDU.

- H-DURKHM. The Emile Durkheim history list focuses on this key figure in the development of sociological thought. Access: LISTSERV@UICVM.CC.UIC.EDU.

- METHODS. Noted research/statistical methods author Earl Babbie's list for social science research methods instructors. Access: METHODS@UNMVMA.UNM.EDU.

- OIC. The Organization Issues Clearinghouse is a multidisciplinary information exchange for organizational researchers. Access: LISTPROC@URAUS.JUN.ALASKA.EDU.

- POR. A forum for public opinion/survey researchers. Access: LISTSERV@GIBBS.OIT. UNC.EDU.

- PSN. The Progressive Sociologists Network addresses issues of class, race, gender, social justice, community, the environment, etc. Participants include members of the American Sociological Association's Marxist Sociology section. Access: LISTPROC@CSF.COLORADO. EDU

- QUALRS-L. A Qualitative Research discussion list. Access: LISTSERV@UGA.CC.UGA. EDU.

- RURSOC-L. Rural Sociology discussion list. Access: LISTSERV@UKCC.UKY.EDU.

- SOCIAL-THEORY. Explores the relationship between sociology and psychology, in- cluding ontological, epistemological, and methodological issues in social psychology. Access: MAILBASE@ MAILBASE.AC.UK.

- SOCORG-K. Social Organization of Knowledge discussion list. Access: LISTSERV@ VM.UTCC.UTORONTO.CA.

- SPORTSOC-L. A Sports Sociology discussion list. Access: LISTSERV@VM.TEMPLE. EDU.

- SSREL-L. The sociology of religion is one focus of this Scientific Study of Religion list. Access: LISTSERV@UTKVM1.UTK.EDU.

\section{Electronic journals}

- Electronic Journal of Sociology. A refereed journal containing articles, commentaries, review essays, and book and software reviews; designed for rapid feedback on current and proposed projects. Access: http:// gpu.srv.ualberta.ca:8010 or ftp.srv.ualberta.ca, cd pub/docs/e-journal.

- Etbno/CA News. Newsletter for researchers in ethnomethodology and conversation analysis. Access: http://www.comp.lancs. ac.uk/sociology/staff/soajeo.html.

- European Sociologist. The European Sociological Association's newsletter for developments on the sociology of Europe. Access: http://www.qub.ac.uk/socsci/miller/submit. html,

- Human Ecology Forum. The leading journal in human ecology. Access: gopher: // gopher.enews.com/11/magazines/ alphabetic/ all/human_ecology/Sub.

- ICPSR Bulletin. The Inter-University Consortium for Political and Social Research (University of Michigan), a membership-based organization, offers access to the world's largest repository of computer-readable social science data. The quarterly ICPSR Bulletin announces data collections most recently released or updated, and ICPSR activities, programs, and services. Access: http://www.icpsr.umich.edu/ ICPSR_homepage.html or gopher://gopher/ icpsr.umich.edu.

- Journal of World-Systems Research. An interdisciplinary scholarly research journal sponsored by the Johns Hopkins Program in Comparative International Development. $A C$ cess: LISTPROC@CSF.COLORADO.EDU, message: subscribe wsn Firstname Lastname.

- New Community: Journal of the European Research Centre on Migration and Ethnic Relations. Contents and abstracts of latest issues are posted with ordering informa- 
tion for print and electronic formats. Access: http://www.ruu.n1/ercomer/index.html.

- Postmodern Culture. This includes analytical essays, reviews, and various literary forms to stimulate discussion of postmodern culture, encouraging reconsideration of traditional forms of academic writing and publishing. Access: http://jefferson.village. virginia.edu/pmc/contents.all.html or $\mathrm{ftp}$. ncsu.edu, cd/pub/ncsu/pmc or LISTSERV@ LISTSERV.NCSU.EDU, message: subscribe pmclist Firstname Lastname.

- Social Science Japan. An English-language newsletter addressing economic, political science, law, and sociological research on Japan. Access: http://www.iss.u=tokyo.ac.jp/ center/SSJ.html.

\section{Subdiscipline-relałed sites}

The following resources illustrate the wealth of information (bibliographic, numeric, and fulltext) on the Internet. Highly specialized sources (e.g., the Anabaptist Sociology \& Anthropology Association homepage) may be identified through the gateway systems listed above.

- Alcoholism Research Data Base. This file includes citations to books, book chapters, journal articles, documents, technical reports, etc., on alcoholism and substance abuse in the Project Cork Resource Center (Dartmouth University). Access: telnet lib.dartmouth.edu, log on and then enter: SELECT FILE CORK.

- Center for the Study of Group Processes. Information about the center (Department of Sociology, University of Iowa), group processes research, researchers, publications, and events around the country. Access: http:/ whw. uiowa.edu/ grpproc.

- Demography \& Population Studies WWW Virtual Library. Provides over 140 links to demographic resources. Access: http:/, coombs.anu.edu.au/ResFacilities/Demography Page.html.

- Disaster Research Center (University of Delaware). Addresses group and organizational preparations for, responses to, and recovery from communitywide emergencies, both natural and technological disasters. Provides information on the center as well as extensive listings of books, monograph series, preliminary papers and project/technical reports, articles, dissertations, etc. Access: gopher:// nisee.ce.berkeley.edu: $70 / 1 / 1 / \mathrm{drc}$.

- Institute for Research on Poverty (IRP) Gopher. Provides information on the institute, its programs, and publications. Instructions for retrieving discussion papers and newsletter features (in PostScript format) are provided. Access: gopher://eunice.ssc.wisc.edu:70/ 1/1/irpgopher.

- Inter-University Consortium for Political and Social Research (ICPSR) Gopher. Provides information on ICPSR, its staff, members, services, and summer training program, with pointers to topical archives, Census 2000 , data archives at other U.S. universities, and social and behavioral science and government Internet services. The ICPSR Guide to Resources and Services is searchable. Access: gopher:// icpsr.umich.edu.

- International Networks for Social Network (INSN) Analysis. Provides background information on INSN, its journal and ftp site, including social network analysis reference resources, course descriptions, and related links. Access: http://home.mcom.com/comprod//mirror/index.html.

- IRSS Public Opinion Data Archives (Institute for Research in Social Sciences, University of North Carolina). Provides access to the General Social Survey codebook with response frequency distributions. Other opinion data inclucte: Louis Harris surveys, USA Today polls, National Network of State polls, Atlanta Joumal Constitution survey, and Latin American public opinion polls. Other IRSS data are also cataloged. For access instructions: gopher://uncmvs.oit.unc.edu:70, select "Getting started."

- Marx \& Engels. Marxist classics in ASCII text files, plus contemporary Marxist material, graphics, and lyrics, and a sound recording of "The Internationale." Access: gopher:/ csf.Colorado.edu: $70 / 1 / 1 / \mathrm{psn} / \mathrm{Marx}$.

- Progressive Sociologists Network (PSN). PSN brings together sociologists worldwide, especially the American Sociological Association's Marxist Sociology section, concerned with progressive issues and values such as working class struggles, civil rights, community development, justice, ecology, and the environment. It provides access to archival material, reviews, syllabi, discussion, etc. $A c$ cess: gopher://csf.Colorado.edu:70/1/1/csf-lists/ psn.

For like-minded resources, see also the Economic Democracy Information Network (EDIN), "the voice of community organizations on the Information Superhighway," providing links to progressive issues and net connections, 


\section{ENVISIONING INFORMATION}

by EDWARD R. TUFTE

\section{WINNER OF 10 BOOK AWARDS}

Phi Beta Kappa Award in Science George Wittenborn Memorial Award ACM Sigdoc, Joseph T. Rigo Award Instructional Development Award AIGA Book Show Award Computer Press Association Book Award Best Graphic Design, ID, Magazine of International Design Association for Computing Machinery, SIGGRAPH Art and Design Show Best Book Design, National Association of Independent Publishers Chairman's Award, International Architecture Book Award, AlA

“Irresistibly beautiful. Envisioning Information is Tufte's second book on information design. His 1983 Visual Display of Quantitative Information is already a classic; the new book is sure to become one as well." COLLEGE \& RESEARCH LIBRARIES

"A remarkable range of examples for the idea of visual thinking, with beautifully printed pages. A real treat for all who reason and learn by means of images." RUDOLF ARNHEIM

"Remarkable. ... Envisioning Information is a marvelously inventive and entertaining stimulus for creative thought." BULLETIN OF THE MEDICAL LIBRARY ASSOCIATION

Over 400 illustrations with exquisite 6 to 12-color printing. Finest examples in technical, creative, business and scientific presentations: diagrams, maps, statistical charts, legal exhibits, computer graphics, and use of color.

Envisioning Information (ISBN 09613921 I 8) \$48 postpaid

The Visual Display of Quantitotive Information (ISBN 096139210 X) $\$ 40$ postpaid

Order directly from the publisher. Moneyback guarantee.

Graphics Press Box 430 Cheshire, Connecticut 06410 
national policy and budget information, third party politics, electoral reform, organizations and movements, magazine and news services, e-mail lists, and fast facts on selected social and economic problems. Access: gopher://garnet. berkeley.edu/:1250/1/

- Society for the Study of Symbolic Interaction (SSSI) Homepage. A social science professional organization for qualitative, especially interactionist, research. The society organizes panels and sessions at annual meetings of the American Sociological Association and other organizations. Access: http://sun.soci.niu. edu/ sssi.

- World-Systems Archive. This electronic archive promotes the free exchange of information on the modern world-system and earlier intersocietal networks, including announcements, documents, books, data, biographical information, bibliographies, newsletters, the Journal of World-Systems Researcb, and the World Systems Network (WSN) listserv archive. Access: gopher://csf.colorado.edu/70/11 wsystems.

\section{Grantsmanship and funding sources gateways}

Internet information on grants, contracts, scholarships, and other financial assistance is found on numerous, reciprocally linked sites. Typical hot-links include the Catalog of Federal Domestic Assistance, Commerce Business Daily, the Federal Register, MOLIS (Minority Online Scholarship Service), FEDIX (Federal Funding Programs Information Exchange), and Foundation Center background information. Below are three excellent gateways.

- Foundation and Grant Information (the University of Michigan). Access: gopher://una.hh.lib.umich.edu; Port 70 , select: genref.

- Grants, Scholarships and Funding (Rice University). Access: gopher:/ riceinfo.rice.edu: $70 / 1 / 1 /$ Subject/Grants.

- GrantsNet (U.S. Department of Health and Human Services). Access: gopher: gopher.os.dhhs.gov, select: DHSS Resources by Topic.

\section{American Sociological Association headquarters}

If you have membership-related queries, the American Sociological Association may be contacted by e-mail at: asa_executive_office@ mcimail.com.

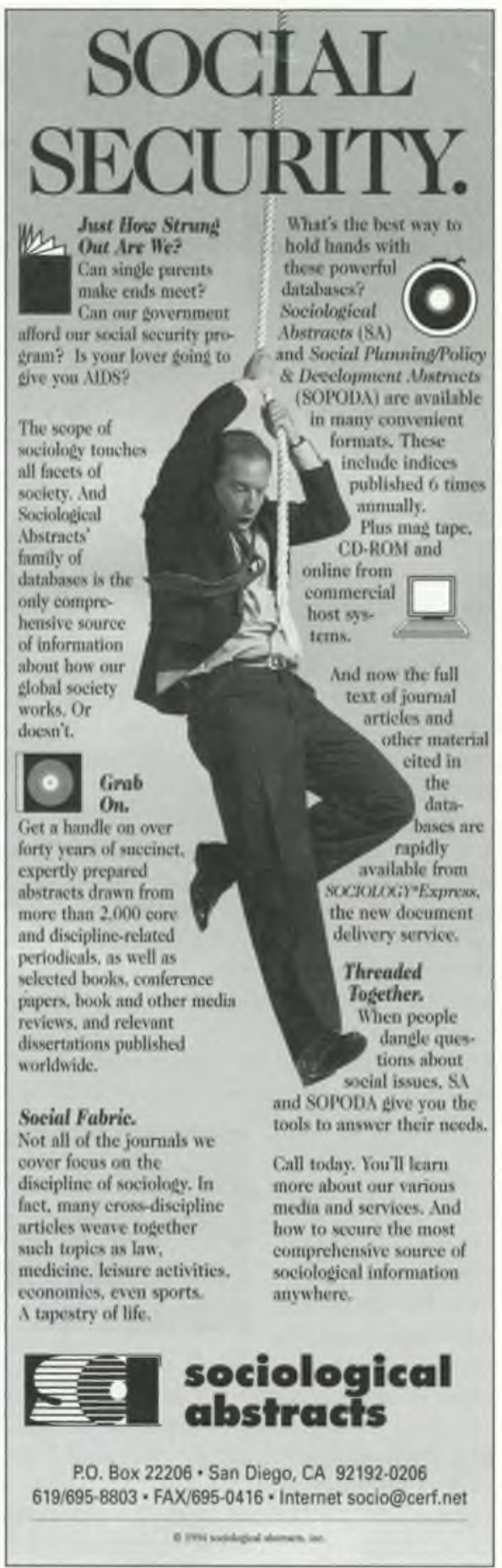

